\title{
イットリウム錯体含有ピツチから得られた メソポア活性炭素紸維の吸着特性と酸処理の影響
}

\author{
佐々木雅彦, 玉井久司*，吉田 猛*，安田 源* \\ (平成 9 年 8 月 7 日受理，平成 9 年 10 月 18 日採択)
}

\section{Dye Adsorption on Mesoporous Activated Carbon Fiber Obtained from Pitch Containing Yttrium Complex and tha Acid Treatment Effects}

\begin{abstract}
Masahiko Sasaki, Hisashi Tamai*, Takeshi Yoshida*, Hajime Yasuda*
The adsorption isotherms of various acid, direct, and basic dyes on mesoporous activated carbon fibers (Y-ACF) obtained from pitch containing $\mathrm{Y}(\mathrm{acac})_{3}$ were measured and the influence of their acid treatment was examined. The Y-ACF highly adsorbed dyes with large molecular size, whereas microporous activated carbon fiber scarcely adsorbed these dyes. Electron probe X-ray microanalysis indicated that yttrium oxide in Y-ACF, which was produced from the yttrium complex, was thoroughly eluted by acid treatment of Y-ACF. The adsorption amounts of acid and direct dyes with large molecular size on Y-ACF decreased by acid treatment. On the other hand, the adsorbed amount of basic dye increased by acid treatment. The adsorption characteristics was associated with the electrostatic properties of the activated carbon fibers.
\end{abstract}

KEYWORDS : Activated carbon fiber, Mesopore, Dye adsorption, Acid treatment

\section{1. 緒 言}

活性炭の細孔は，そのサイズによりミクロポア $(<2.0 \mathrm{~nm})$, メソポア (2.0〜50nm), マクロポア (>50nm) に分類され るが, 現在製造され用いらられている活性炭は, 出発原料や 賦活方法などの製造方法等に違いがあってもミクロポアから なっているものが多い1，2)。一方，比表面積に関しては，多 くの活性炭が1000 $1500 \mathrm{~m}^{2} / \mathrm{g}$ の比表面積を有するが，アル カリを用いた薬品賦活法により $2500 \mathrm{~m}^{2} / \mathrm{g}$ 以上の大きな比表面 積を有する活性炭が得られることが報告されている3)-5)。活 性炭の吸着特性は主として細孔の大きさ，形状，その分布お よび比表面積等に関係している(6)-13)。また，上述のミクロポ アが発達した活性炭の場合, 比較的分子サイズの小さい吸着 質に対しては高い吸着性を有するが，巨大分子に対する吸着 性は低い14) -18)。

すでに著者らは, $\mathrm{Y}(\mathrm{acac})_{3}$ を含有するピッチを水蒸気賦活 することにより，高BET比表面積を有し，かつ高度にメソポ アが発達した活性炭素瀻維 (メソポア活性炭素繊維) が得ら れることを報告した19)-21)。また，これらのメソポア活性炭
素㵶維が分子サイズの大きいビタミン $\mathrm{B}_{12}$, フミン酸, シク ロデキストリン等の巨大分子の吸着特性に優れていることも 報告した ${ }^{20)}$ 。

一方，活性炭の吸着性は上述の表面積および細孔サイズな どの物理的要因に加えて, 細孔表面の組成および官能基の有 無など化学的要因にも影響される22)-26)。本研究では, Y (acac) 3 含有ピッチを出発原料として得られたメソポア活性 炭素繊維を，硝酸で処理して金属のイットリウムを除去する ことを試みた。この酸処理が活性炭素織維の細孔特性㧍よび 吸着特性へ及ほす影響について調べるために, 酸性, 直接, 塩基性染料など種々の染料分子の吸着性を検討した。

\section{2. 実 験}

\section{1 活性炭素絩維}

メソポア活性炭素瀻維は，著者らが開発した方法20)にし たがってY $(\mathrm{acac}){ }_{3}$ を含有するピッチを紡系後, 水蒸気で飽和 したN $\mathrm{N}_{2}$ ガスで賦活することにより得た (Y-ACFと略)。金属 を含有しないピッチ繊維から得られたミクロポアの発達した 活性炭素纎維は，市販の活性炭素瀻維（アドール社製，A-20

比治山女子短期大学生活学科： 7732 広島市東区牛田新町4-1-1

Hijiyama Women's College : 4-1-1, Ushitashinmachi, Hiroshima 732, Japan

* 広島大学工学部: 7739 東広島市鏡山1-4-1

Faculty of Engineering, Hiroshima University : 1-4-1, Higashihiroshima, Hiroshima 739, Japan 
と略）を用いた。

\section{2 染 料}

染料は, 酸性染料としてAcid Red 88 (Sigma), Acid Red 13 (東京化成), Acid Blue 90 (大和化工) を, 直 接染料としてDirect Red 2 (和光純薬), Direct Yellow 11 (大和化工), Direct Black 22 (住友染料テック) を, また塩基性染料としてBasic Blue 9 (Methylene Blue, 和光純薬）をそれぞれChavanの方法27)にしたがって精製し， $105^{\circ} \mathrm{C}$ で真空乾燥して用いた。これらの染料分子の立体構造 およびサイズは分子モデリングソフトCACheにより, 古典 力学的方法により最適化して求めた。また, 分子サイズは原 子間距離として表わした。

\section{3 方 法}

活性炭素繊維のBET比表面積, 全細孔容積等の細孔特性は Autosorb-6 (Quantachrome) を使用し， N 2 ガス吸着法によ り求めた。平均細孔径, メソポア細孔容積およびメソポア比 表面積はBJH法28)により算出した。酸処理は活性炭素䋐維約 $4 \mathrm{~g}$ を $1 \mathrm{~N}$ 硝酸水溶液 51 中に浸せき，2時間擋拌する操作を 3 回 繰り返した。処理後の活性炭素瀻維は洗浄水の $\mathrm{pH}$ ガ中性を 示すまで十分水洗した。活性炭素繊維中のイットリウムの状 態および量は電子線プローブX線マイクロアナリシス (EPMA) により調べた。染料の吸着量は, 三角フラスコに 染料水溶液 $50 \mathrm{ml}$ と活性炭素繊維 $20 \mathrm{mg}$ を入て $25^{\circ} \mathrm{C}$ の恒温 水槽中でしんとう擋找し, 吸着前後の染料濃度の変化から求 めた。活性炭素䋐維の 電位は, 乳鉢により微粉砕後水に分 散させ, 顕微鏡電気泳動法により求めた。なお、分散液の $\mathrm{pH}$ は $\mathrm{HCl}$ と $\mathrm{NaOH} て ゙$ 調整し, 系全体のイオン強度を $\mathrm{NaCl}$ 一定に保った。細孔を有する場合, 電気泳動法による表面電 位の算出には問題点を有しているが, ここでは表面電位の目 安として, 電気泳動移動度かSmoluchowski式によりら電位 を算出した。

\section{3. 結果と考察}

\section{1 活性炭素絨維}

$\mathrm{Y}(\mathrm{acac})_{3}$ を含有するピッチを賦活することにより得られ たメソポアが発達した活性炭素繊維および純ピッチから得ら れたミクロポアが発達した活性炭素繊維の酸処理前（それぞ
れY-ACFおよびA-20)，および酸処理後（Y-ACF-Aおよび A-20-A と略）のN $\mathrm{N}_{2}$ ガス吸脱着等温線をFig.1に示した。YACFの場合, 高相対蒸気圧側でヒステリシスを示した。これ らの吸着等温線から求めたBET比表面積, 細孔径などの細孔 特性值をTable1に示した。Y-ACFおよびA-20のいずれの活 性炭素䋐維においても, 酸処理によりBET比表面積, 全細孔 容積が少し増加し，また平均細孔径も増加する傾向を示した。

メソポア活性炭素繊維の繊維長および繊維軸方向のイット リウムに関するEPMA写真をFig.2に示した。この写真から 活性炭素㵶維中にイットリウム化合物の微粒子 $\mathrm{Y}_{2} \mathrm{O}_{3}$ が均一 に分散していることがわかる。賦活を通じてY錯体は $\mathrm{Y}_{2} \mathrm{O}_{3}$ に 酸化され，これらの微粒子が活性炭素繊維中に分散している ものと考えられる（既報においてX線粉末回折から賦活によ り $\mathrm{Y}_{2} \mathrm{O}_{3}$ が生成することを報告した201)。一方, 酸処理したメ ソポア活性炭素繊維（Y-ACF-A）のEPMA観察では, 未処 理活性炭素中に観察されたイットリウムは完全に消失し, 微 粒子 $\mathrm{Y}_{2} \mathrm{O}_{3}$ の存在は認められなかった。また, Y-ACF活性炭 素瀻維から1N硝酸処理液中に溶出するY量と活性炭素䋐維の 浸漬時間の関係を求めたところ (Fig.3), 未処理Y-ACFのY (EPMAによる含有量2.02wt％) は浸漬時間2時間でほぼ全量 溶出した。これらの結果から, 賦活により生成した活性炭素 緎維中の $\mathrm{Y}_{2} \mathrm{O}_{3}$ は硝酸処理によりほぼ完全に除去されること
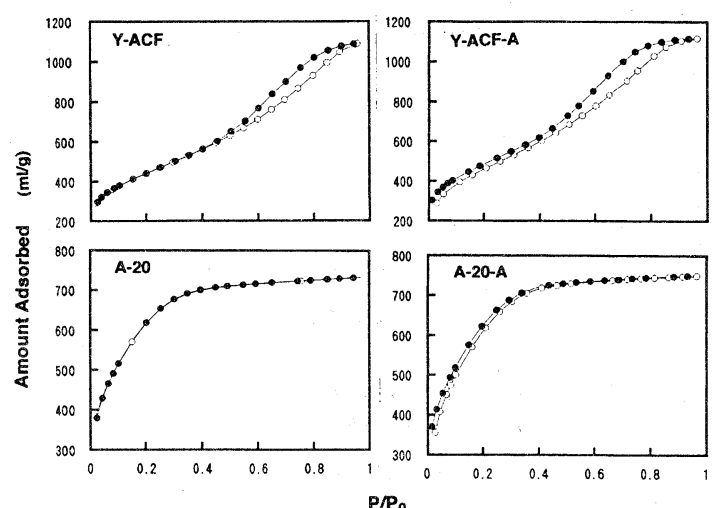

Fig.1 Adsorption-desorption isotherms of $\mathrm{N}_{2}$ for the activated carbon fibers. open circles : adsorption, closed circles : desorption.

Table1 Pore characteristics of activated carbon fibers

\begin{tabular}{lcccccc}
\hline activation & $\begin{array}{c}\text { BET } \\
\text { surface area } \\
\left(\mathrm{m}^{2} / \mathrm{g}\right)\end{array}$ & $\begin{array}{c}\text { total } \\
\text { pore volume } \\
(\mathrm{ml} / \mathrm{g})\end{array}$ & $\begin{array}{c}\text { mesopore } \\
\text { surface area } \\
\left(\mathrm{m}^{2} / \mathrm{g}\right)\end{array}$ & $\begin{array}{c}\text { mesopore } \\
\text { volume } \\
(\mathrm{ml} / \mathrm{g})\end{array}$ & $\begin{array}{c}\text { pore size } \\
(\mathrm{Cm})\end{array}$ \\
\hline Y-ACF & $875-35$ & 1554 & 1.689 & 1248 & 1.513 & 4.36 \\
Y-ACF-A* & - & 1659 & 1.823 & 1189 & 1.499 & 4.40 \\
A-20 & $875-70$ & 1990 & 1.100 & 92 & 0.100 & 2.14 \\
A-20-A* & - & 2176 & 1.216 & 45 & 0.188 & 2.24 \\
\hline *-An
\end{tabular}


が明らかになった。また，Y $(\mathrm{acac})_{3}$ 含有ピッチから得られた 活性炭素瀻維中の $\mathrm{Y}_{2} \mathrm{O}_{3}$ 微粒子は, 活性炭素の炭素質中に埋 没して存在しているのではなく, 活性炭繊維の細孔表面上か あるいは一部を細孔表面に露出して存在しているものと考え られる。

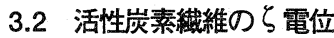

各活性炭素䋐維のら電位とpHの関係をFig.4 に示した。イ ットリウム賦活活性炭Y-ACFおよびこれを酸処理した活性
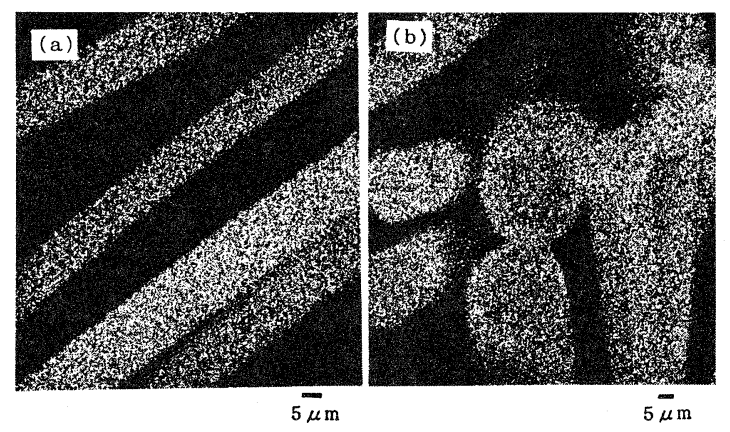

Fig.2 EPMA image of Y-ACF with regard to yttrium species : (a) horizontal, (b) vertical.

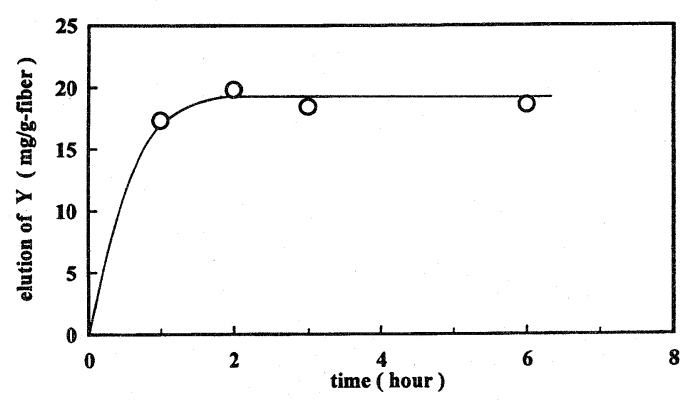

Fig.3 Elution of yttrium compound from Y-ACF (Y content $20.2 \mathrm{mg} / \mathrm{g}$ ) in $1 \mathrm{NHNO}_{3}$.

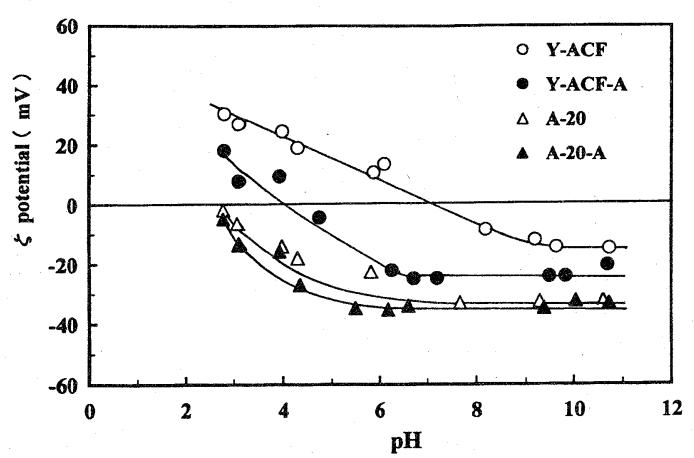

1Fig.4 $\zeta$-Potential of activated carbon fibers.
炭Y-ACF-Aは等電点を有し, 酸性側では正の電位をまたア ルカリ性側では負の電位を示した。またA-20活性炭素繊維 では明白な等電点を示さなかった。Y-ACFの場合には, 生 成した $\mathrm{Y}_{2} \mathrm{O}_{3}$ が水と接してY $(\mathrm{OH})_{3}$ を生じるため正の電位を示 すものと考えられる。このような等電点の存在は， $\mathrm{Dai}^{29)}$ の 報告にも見られる。またA-20の場合，電位は酸処理により ほとんど変化しないのに対し，Y-ACFの場合, 酸処理によ り等電点か酸性側に大きく移行し, 中性付近では活性炭素緎 維表面のら電位が正から負に逆転した。これらの結果からY$\mathrm{ACF}$ 場合, 酸処理により $\mathrm{Y}_{2} \mathrm{O}_{3}$ 微粒子が溶解除去されて, 新しく炭素表面が露出するとともに, 酸化等により酸性の解 離基が生成することが考えられる。

\section{3 染料の吸着速度}

酸性染料Acid Red 88 および直接染料Direct Black 22 の未 処理A-20およびY-ACFへの吸着量に及ほす時間の影響を Fig.5,6に示した。いずれの染料も時間とともに吸着量は増加 し，2時間でほほ平衡に達した。小さい分子のAcid Red 88 は 吸着平衡時間が短いが，巨大分子のDirect Black 22のそれは 少し長くなる傾向が認められた。その分子サイズが巨大であ るにもかかわらず比較的短時間で平衡に達した。したがって,

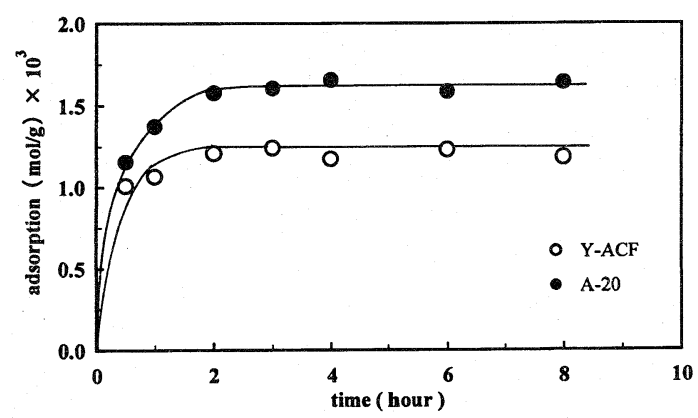

Fig.5 Adsorption rate of Acid Red 88 on the activated carbon fibers (dye concentration : $5.21 \times 10^{-4} \mathrm{~mol} / \mathrm{l}$ ).

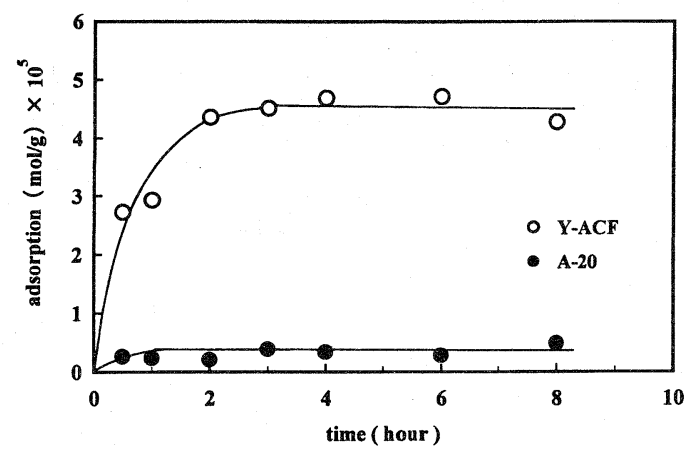

Fig.6 Adsorption rate of Direct Black 22 on the activated carbon fibers (dye concentration : $4.46 \times 10^{-5} \mathrm{~mol} / \mathrm{l}$ ). 

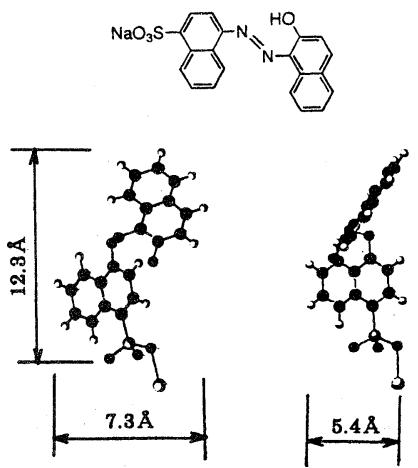

Acid Red 88

(a)
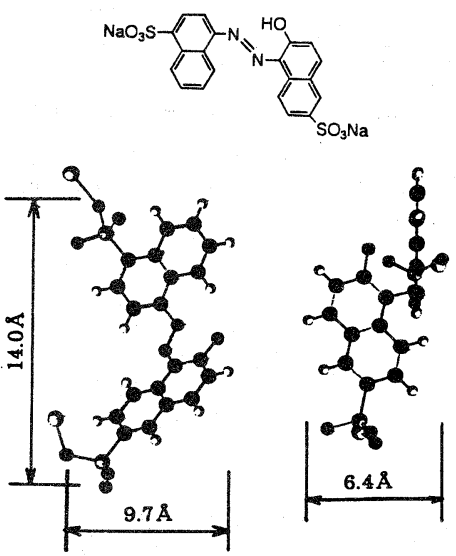

Acid Red 13

(b)
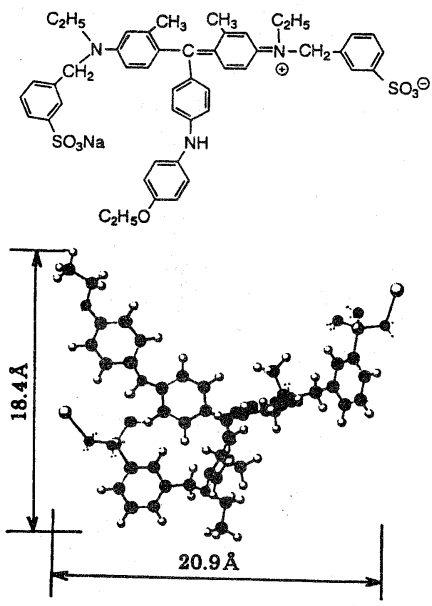

Acid Blue 90

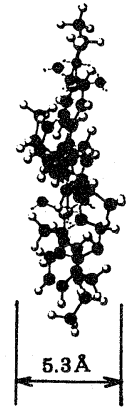

(c)

Fig.7 Molecular structures of acid dyes.
細孔内への染料分子の浸透拡散は短時間で起こるものと考え られる。酸処理活性炭素繊維においても同様な吸着速度を示 した。また，他の染料の場合にも，2時間の吸着時間でほほ 平衡に達した。これらの結果より，吸着時間を3時間として 中性水溶液中における吸着等温線を求めた。

\section{4 酸性染料の吸着性}

酸性染料Acid Red 88，Acid Red 13およびAcid Blue 90 (Fig.7にそれぞれの立体構造およびサイズを示す）の未処理 および酸処理活性炭素繊維へ吸着等温線をFig.8に示した。 Acid Red 88の場合, 分子サイズも小さく, その上, 親水性 の酸性基（- $\mathrm{SO}_{3} \mathrm{Na}$ ) を一つしか有しないことなどからいず れの活性炭素緎維に対しても高い吸着量を示した。また，そ の吸着量はY-ACFよりも比表面積の大きいA-20に対して多 かった。また，酸処理による吸着量の低下もAcid Red 13 に 比べてわずかであった。同一の化学構造を有し, 親水性の$\mathrm{SO}_{3} \mathrm{Na}$ 二つ有するAcid Red 13 の場合, Acid Red 88 よりも 吸着量は未処理A-20を除き約 $1 / 2$ 量位低くなり, また, 酸処 理による減少も顕著であった。Y-ACFの場合，酸処理によ り活性炭素纎維の負の 電位が増加することから, 活性炭素 繊維表面とアニオン性の染料分子との間の静電的反発力が増 加するため吸着量が減少するものと考えられる。一方，より 巨大分子であるAcid Blue 90 の場合，ミクロポアからなるA20にはあまり吸着しないのに対し，メソポアが発達したYACFには高い吸着量を示した。A-20の場合，Acid Blue 90の 分子サイズが大きいためミクロポア内への浸透拡散が制限さ れ，吸着に関与する有効表面積が低くなるものと考えられる。 また, 酸処理Y-ACFへの吸着量は未処理㵶維に比較して吸 着量が急激に減少した。これはら電位と $\mathrm{pH}$ の関係から, 酸 処理により $\mathrm{Y}_{2} \mathrm{O}_{3}$ が除去されるとともに炭素表面が酸化され 酸性基が生成するために細孔表面と染料分子間の静電的反発 力が増加することが考えられる。この結果細孔内に染料分子

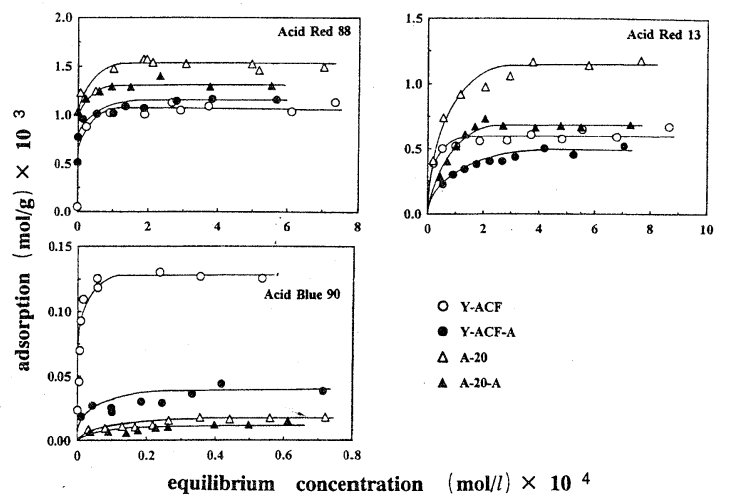

Fig.8 Adsorption isotherms of acid dyes on the activated carbon fibers. 
が拡散しても, 静電的反発力のため吸着量が減少するものと 考えられる。

\section{5 直接染料の吸着性}

直接染料Direct Red 2, Direct Black 22およびDirect Yellow 11 (Fig.9にそれぞれの立体構造およびサイズを示す) の吸 着等温線をそれぞれFig.10に示した。これら3種の染料の場 合，未処理および酸処理のA-20にはあまり吸着しないのに 対し，未処理Y-ACFには高い吸着量を示した。いずれの染 料においてもその分子サイズが大きいことから，ミクロポア を主体とした活性炭素繊維A-20が高BET比表面積を有する

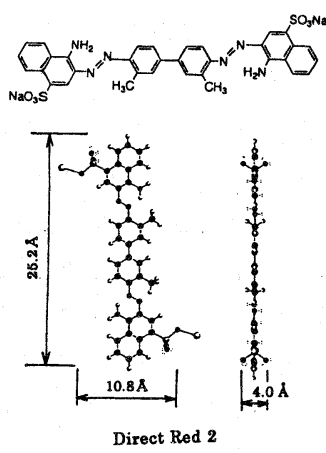

(a)

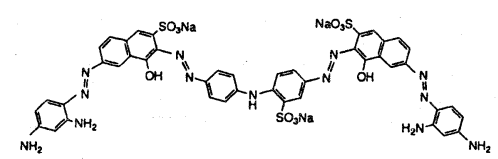

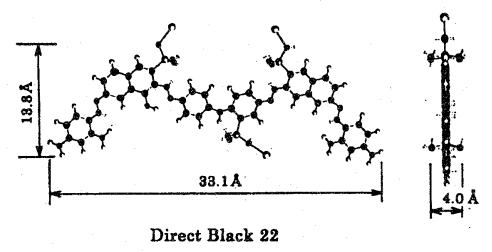

(b)
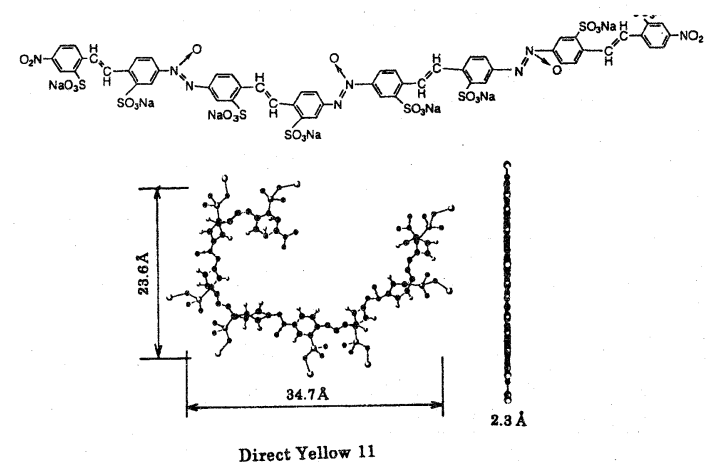

(c)

Fig.9 Molecular structures of direct dyes.
にもかかわらず細孔内へ染料分子の拡散ができないために吸 着量が小さいものと考えられる。一方，メソポア活性炭素緎 維Y-ACFの場合, 直接染料がメソポアにも吸着し，正の電 位を有している活性炭表面とアニオン性の染料分子との間に

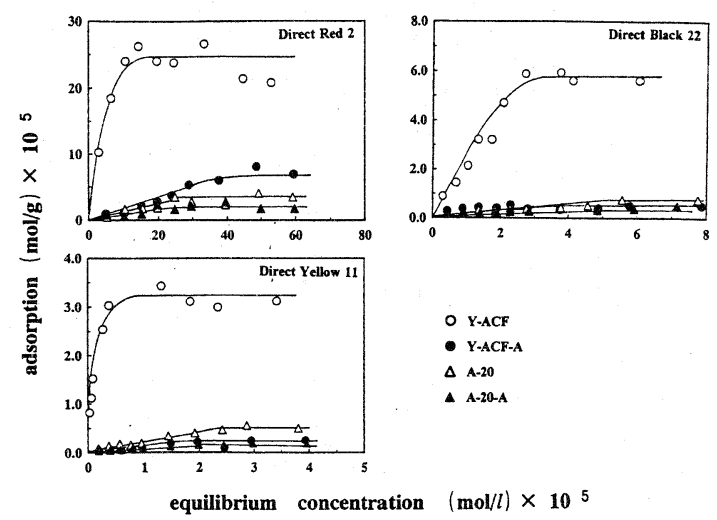

Fig.10 Adsorption isotherms of direct dyes on the activated carbon fibers.
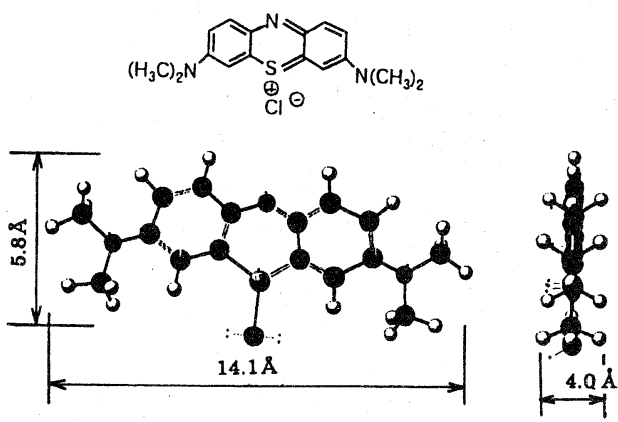

Basic Blue 9

Fig.11 Molecular structure of basic dye.

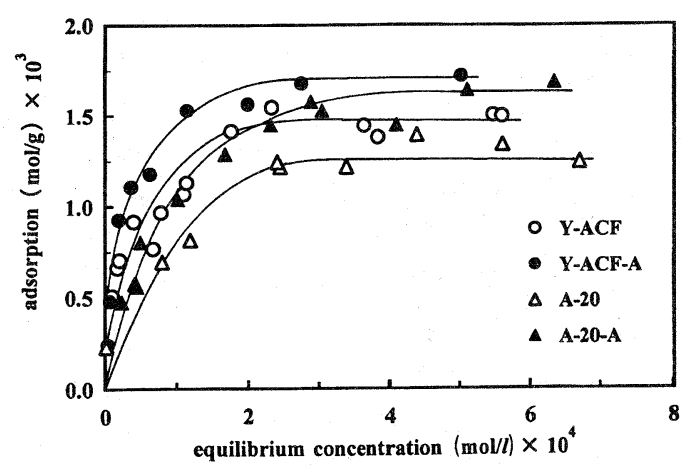

Fig.12 Adsorption isotherms of Basic Blue 9 on the activated carbon fibers. 
Table 2 Occupied areas of dye molecles on activated carbon fibers.

\begin{tabular}{|c|c|c|c|c|c|c|c|c|c|}
\hline \multirow[t]{2}{*}{ Dye } & \multicolumn{2}{|c|}{ Y-ACF } & \multicolumn{2}{|c|}{ Y-ACF-A } & \multicolumn{2}{|c|}{ A-20 } & \multicolumn{2}{|c|}{ A-20-A } & \multirow{2}{*}{$\begin{array}{c}\text { Cross section } \\
\left(\AA^{2} / \text { dye }\right)\end{array}$} \\
\hline & $\begin{array}{c}\text { saturated } \\
\text { adsorption } \\
(\mathrm{mol} / \mathrm{g})\end{array}$ & $\begin{array}{c}\text { occupied } \\
\text { area } \\
\left(\AA^{2} / \text { dye }\right)\end{array}$ & $\begin{array}{c}\text { saturated } \\
\text { adsorption } \\
(\mathrm{mol} / \mathrm{g})\end{array}$ & $\begin{array}{c}\text { occupied } \\
\text { area } \\
\left(\AA^{2} / \text { dye }\right)\end{array}$ & $\begin{array}{c}\text { saturated } \\
\text { adsorption } \\
(\mathrm{mol} / \mathrm{g})\end{array}$ & $\begin{array}{c}\text { occupied } \\
\text { area } \\
\left(\AA^{2} / \text { dye }\right)\end{array}$ & $\begin{array}{c}\text { saturated } \\
\text { adsorption } \\
(\mathrm{mol} / \mathrm{g})\end{array}$ & $\begin{array}{l}\text { occupied } \\
\text { area } \\
\left(\AA^{2} / \text { dye }\right)\end{array}$ & \\
\hline Acid & $1.13 \times 10^{-3}$ & 203 & $1.13 \times 10^{-3}$ & 228 & $1.50 \times 10^{-3}$ & 220 & $1.29 \times 10^{-3}$ & 256 & 90 \\
\hline Acid Blue 90 & $1.27 \times 10^{-4}$ & 1800 & $8 \times 10^{-5}$ & 7890 & $1.64 \times 10^{-5}$ & 20100 & $9.55 \times 10^{-6}$ & 34600 & 385 \\
\hline Direct Red 2 & $2.51 \times 10^{-4}$ & 913 & $6.82 \times 10^{-5}$ & 3780 & $3.82 \times 10^{-5}$ & 8650 & $1.64 \times 10^{-5}$ & 20200 & 272 \\
\hline Direct Yellow 11 & $3.16 \times 10^{-5}$ & 7250 & $2.18 \times 10^{-6}$ & 118000 & $4.36 \times 10^{-6}$ & 75800 & $1.09 \times 10^{-6}$ & 303000 & 819 \\
\hline Basic Blue 9 & $1.44 \times 10^{-3}$ & 159 & $1.72 \times 10^{-3}$ & 150 & $1.61 \times 10^{-3}$ & 205 & $1.26 \times 10^{-3}$ & 262 & 82 \\
\hline
\end{tabular}

静電的引力が作用するため吸着量が多くなるものと考えられ る。また, 酸処理した活性炭表面は負の電位を有するためア ニオン性の染料分子との間に静電的反発力が㗢き，この結果 細孔内に染料分子が拡散しても吸着量が未処理活性炭素繊維 に比較して少さくなるものと考えられる。

\section{6 塩基性染料の吸着性}

塩基性染料Basic Blue 9 (Fig.11に立体構造およびサイズ を示す) の吸着等温線をFig.12に示す。分子サイズの比較的 小さい塩基性染料の場合，A-20およびY-ACFいずれの活性 炭素繊維に対しても, 酸性抢よび直接染料と比較して高い吸 着量を示した。これは染料の分子サイズが非常に小さいうえ にカチオン性の染料と負に带電している活性炭素繊維表面と の間に静電的引力が働き，大きな吸着量を示すものと考えら れる。未処理Y-ACFの場合には, 正の活性炭表面とカチオ ン性の染料との間に静電的反発力が㗢くが, 逆に酸処理YACFの場合には, 細孔表面の電位が負に変わり静電的引力が 働くため吸着量が多くなるものと考えられる。

\section{7 染料分子の占有面積}

染料の飽和吸着量とBET比表面積から求めた各染料の, そ れぞれの活性炭素瀻維表面の分子占有面積および染料分子の 立体構造の長軸方向と短軸方向の長さから求めた染料の断面 積をTable2 に示した。吸着等温線から予測されるように巨 大分子サイズの酸性染料および直接染料の分子占有面積は, 染料断面積に比較して非常に大きな值を示し，染料分子はか なり疎な状態で吸着しているとも考えられる。大きな染料 分子の場合, ミクロポアの表面か吸着に対して有効な表面と ならないことを示唆している。一方, 塩基性染料の場合, 分 子占有面積と断面積が同程度の值を示すことから, 染料分子 は活性炭細孔表面にフラットな状態で密に吸着しているもの と考えられる。塩基性染料は分子容積が小さいためミクロポ アの細孔に容易に浸透拡散できることと, 活性炭素繊維の表 面と塩基性染料との間に静電的引力が㗢くため密な吸着状態 となるものと考えられる。

\section{4. 結 論}

現在市販されているミクロポアが発達した活性炭素繊維と 比較して,メソポアが高度に発達したY $(\mathrm{acac})_{3}$ 含有ピッチか ら得られた活性炭素絨維は, 分子サイズの大きい染料の吸着 に対して，非常に高い吸着性を示した。メソポア活性炭素㵶 維を酸処理すると, 活性炭賦活時に生成した $\mathrm{Y}_{2} \mathrm{O}_{3}$ はほぼ完 全に溶出し, 活性炭の等電点は大きく酸性側に移動し, 中性 付近では表面の電位が正から負に変わることが明らかになっ た。このためメソポア活性炭素瀻維の染料吸着量は, 酸性お よび直接染料の場合, 酸処理により吸着量が減少するのに対 し，逆に塩基性染料のそれは増加した。これらのことから大 きな染料分子の吸着に対しては, 分子サイズに合う細孔径と その比表面積さらにその表面電位が大きく関与していること が示唆された。

\section{謝辞}

EPMA観察においてご協力を頂きました，大阪ガス侏)基盤 研究所水取重司氏に謝意を表します。

本研究は, 一部文部省科学研究費（重点領域研究 “カーボ ンアロイ”課題番号09243228,1997.) の援助

によるものであり,ここに謝意を表します。

\section{文献}

1）吸着技術ハンドブック（清水博 監修）（1993）エス。 テイ・エヌpp.118-175.

2) F.R.-Reinoso and M.M.Sabio, Carbon, 30 (1992) 11111118.

3) H.Marsch and D.Crawford, Carbon, 20 (1982) 419-426.

4) A.N.Wennerberg and T.M.O'Grady, US Patent, 4082694.

5) 音羽利郎, 科学と工業, 64 (1990) 331-335.

6) C.H.Rochester and A.Strachan, J.Colloid Interface Sci., 177 (1996) 339-342.

7）笠岡成光, 阪田祐作, 田中栄治, 内藤龍之介, 日化, 1987, 990-100.

8）笠岡成光, 田中栄治, 阪田祐作, 内藤龍之介, 日化, 1987, 2267-2273.

9）笠岡成光, 田中栄治, 阪田祐作, 内藤龍之介, 日化, 1987, 2260-2266.

10）田中栄治, 内藤龍之介, 阪田祐作, 笠岡成光, 日化, 1988,1549-1555. 
11) A.Matsumoto, J.-X.Zhao and K.Tsutsumi, Langmuir, 13 (1997) 496-501.

12) N.E.Krupa and F.S.Cannon, J.Am.Water Works Assoc., 88 (1996) 94-108.

13) K.Ogino, Y.Kaneko, T.Minoura, W.Agui and M.Abe, J.Colloid Interface Sci., 121 (1988) 161-169.

14) C.Brasquet, J.Roussy, E.Subrenat and P.Le Cloirec, Environ.Technol., 17 (1996) 1245-1252.

15) P.Le Cloirec,C.Brasquet and E.Subrenat, Energy Fuels, 11 (1997) 331-336.

16) W.J.Weber Jr., T.C.Voice and A.Jodellah, J.Am. Water Works Assoc., 75 (1983) 612-619.

17) J.Starek, A.ZukalandJ.Rathousky, Carbon, 32 (1994) 207-211.

18）山口達明, 佐藤嘉久, 小林左東司, 日化, 1993, 285-289.

19) H.Tamai, T.Kakii, Y.Hirota, T.Kumamoto and H.Yasuda, Chem.Mater., 8 (1996) 456-462.
20）玉井久司, 小島重行, 池内真貴子, 水取重司, 金田隆義, 安 田源, 炭素, 1996, 243-248.

21) H.Tamai, M.Ikeuchi, S.Kojima and H.Yasuda, Ad. Mater., 9 (1997) 55-58.

22) H.G.Prabu and A.Kaspar, Text.Dyer Printer, 27 (1994) 19-21.

23) S.H.Lin, J.Chem.Tech.Biotechnol., 58 (1993) 159-163.

24) R.Yu Li Yeh and A.Thomas, J.Chem.Tech. Biotechnol., 63 (1995) 55-59.

25) G.Newcombe, J.Colloid Interface Sci., 164 (1994) 452462.

26) G.Morris and G.Newcombe, J.Colloid Interface Sci., 159 (1993) 413-420.

27) R.B.Chavan, Textile Research J., 46 (1976) 435-437.

28) E. P. Barrett, L. S. Joyner and P.P.Halenda, J.A.C.S., 73 (1951) 373-377.

29) M.Dai, J.Colloid Interface Sci., 164 (1994) 223-228. 